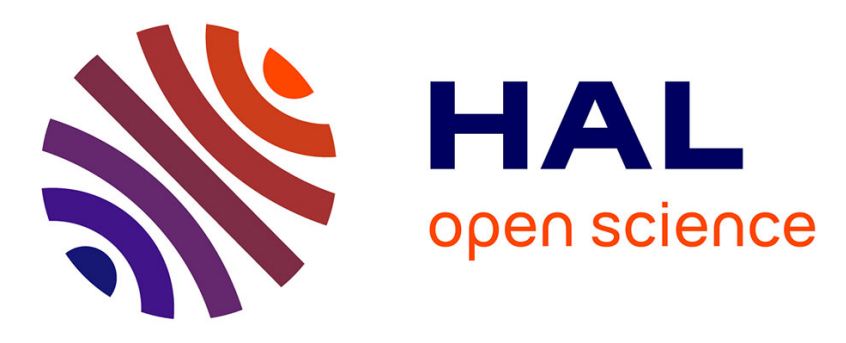

\title{
Changing patterns in climate-driven landslide hazard: an alpine test site
}

Audrey Baills, Rosalie Vandromme, Nicolas Desramaut, Olivier Sedan, Gilles Grandjean

\section{- To cite this version:}

Audrey Baills, Rosalie Vandromme, Nicolas Desramaut, Olivier Sedan, Gilles Grandjean. Changing patterns in climate-driven landslide hazard: an alpine test site. The Second World Landslides Forum, Oct 2011, Rome, Italy. pp.4. hal-00631008

\section{HAL Id: hal-00631008 https: / hal-brgm.archives-ouvertes.fr/hal-00631008}

Submitted on 11 Apr 2012

HAL is a multi-disciplinary open access archive for the deposit and dissemination of scientific research documents, whether they are published or not. The documents may come from teaching and research institutions in France or abroad, or from public or private research centers.
L'archive ouverte pluridisciplinaire HAL, est destinée au dépôt et à la diffusion de documents scientifiques de niveau recherche, publiés ou non, émanant des établissements d'enseignement et de recherche français ou étrangers, des laboratoires publics ou privés. 


\title{
Changing patterns in climate-driven landslide hazard: an alpine test site
}

\author{
Audrey Baills ${ }^{(1)}$, Rosalie Vandromme ${ }^{(1)}$, Nicolas Desramaut ${ }^{(1)}$, \\ Olivier Sedan - Miegemolle ${ }^{(1)}$, and Gilles Grandjean ${ }^{(1)}$ \\ (1) BRGM, Risks division, 3 avenue Claude Guillemin, BP36009, 45060 Orléans Cedex 2, France. +33 238644798
}

\begin{abstract}
The aim of this work is to develop a methodology for integrating climate change scenarios into quantitative hazard assessment and especially their precipitation component. The effects of climate change will be different depending on both the location of the site and the type of landslide considered. Indeed, mass movements can be triggered by different factors. This paper describes a methodology to address this issue and shows an application on an alpine test site.

The proposed approach is based on coupling a hydrological model (GARDENIA ${ }^{\circledR}$ ) with a slope stability model $\left(\right.$ ALICE $\left.^{\circledR}\right)$, estimating safety factors spatially. From a DEM, land-cover map, geology, geotechnical data and so forth the program classifies hazard zones depending on geotechnics and different hydrological contexts varying in time. The methodology is applied to the Ubaye valley (France) using present and past climate conditions.
\end{abstract}

Keywords: hazard, landslide, climate change, hydrology

\section{Introduction}

In the next century climate change will lead to a modification of various meteorological parameters. The modifications of precipitation quantities and the variations in the spatial and temporal distributions of extreme events are some of the probable changes that should have an important impact on rainfall-induced landslides. However, development plans and mitigation measures are often designed for estimated impacts from hazard assessments based on past data and existing contexts, neglecting potential influences due to global change. These changes should be incorporated in the decision making process so that measures and plans will have longer validity.

In order to estimate the changing pattern of landslide activity, we present in the following a combination of models used to integrate these rainfall scenarios into quantitative landslide hazard assessments.

\section{Models and Method}

\section{Models}

\section{GARDÉNIA}

The GARDÉNIA ${ }^{\circledR}$ V.7.o software package has been developed by BRGM for lumped hydrological modelling of rainfallrunoff and aquifer level (Thiery, 2003). The GARDÉNIA ${ }^{\circledR}$ model simulates the water cycle from rainfall received by the soil surface until the outlet, either as the discharge rate or as the aquifer level at a given point. The hydrological system is modelled by a system of 3 or 4 tanks (top tens of centimetres of soil, where evapotranspiration occurs; an intermediate level, where runoff occurs; and one or two aquifer zones, with delayed flows). 


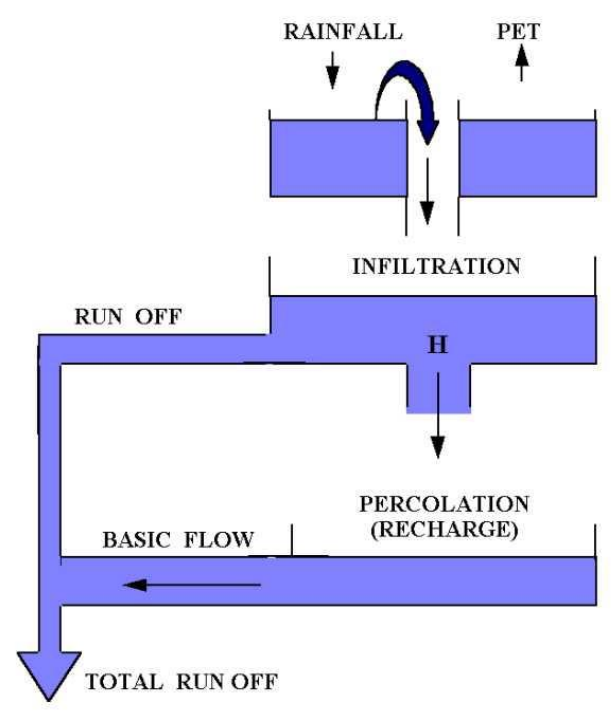

Figure 1: Schematic representation of GARDÉNIA®'s operating principle

Hence, it allows the simulation of the relationships between series of:

- discharge data of a spring or stream and rainfall amounts received by the corresponding basin; and

- piezometric levels in an aquifer and amounts of rainfall received by the corresponding basin.

This modelling involves 4 to 6 lump parameters (soil and atmospheric characteristics). These parameters have to be calibrated using rainfall and water level data from past records.

\section{ALICE $^{\circledR}$, Assessment of Landslides Induced by Climatic Events}

ALICE $^{\circledR}$ (Sedan, 2011) is a software developed by BRGM whose main function is to produce landslide hazard maps, based on slope stability analysis, at various scales, from the single slope to hundreds of square kilometres. It was conceived as a tool within quantitative landslide risk assessment, which could be applied homogeneously on the whole French territory. Its principal components are:

- a finite slope stability model using the method of Morgenstern and Price (1967) applied at regular intervals of the 2D topographic profiles;

- a geographical Information System (GIS) since the software operates spatially; and

- the management of the variability and uncertainties of geotechnical parameters (through probability distributions).

The results are expressed either as a safety factor or a probability that this safety factor is below unity (instability).

A more detailed description of the software can be found in (Olivier et al., this issue).

In ALICE $^{\circledast}$, water in soil influences pore pressure. For the moment, the water component is simply introduced through the level of the saturated layer.

\section{Method}

The methodology proposed in this work is based on the coupling of both tools described above (Figure 2).

1 - GARDENIA converts meteorological inputs (either from past observations, current predictions or climate change models) into filling ratios of the different tanks.

2 - The filling ratio of the intermediate tank is then converted to the level of the saturated layer into ALICE ${ }^{\circledR}$ using minimum and maximum piezometric maps. These maps are established thanks to piezometric data and SIG hydrological calculations weighted by experts.

3- ALICE $^{\circledR}$ computes probabilistic distributions of the safety factor for each profile.

4 - Susceptibility (equal to the probability of the safety factor being below unity) is mapped.

Hence, after a calibration phase for both tools, based on available observations of rainfall events, water table levels and historical landslides, this methodology computes an estimate of the susceptibility for rainfall-induced landslides that could occur at the regional scale. Meteorological events gather all information from forecasts for near-future events to 
scenarios from climate change models for further periods. This is particularly useful in evaluating changing patterns of landslide activities due to climate change.

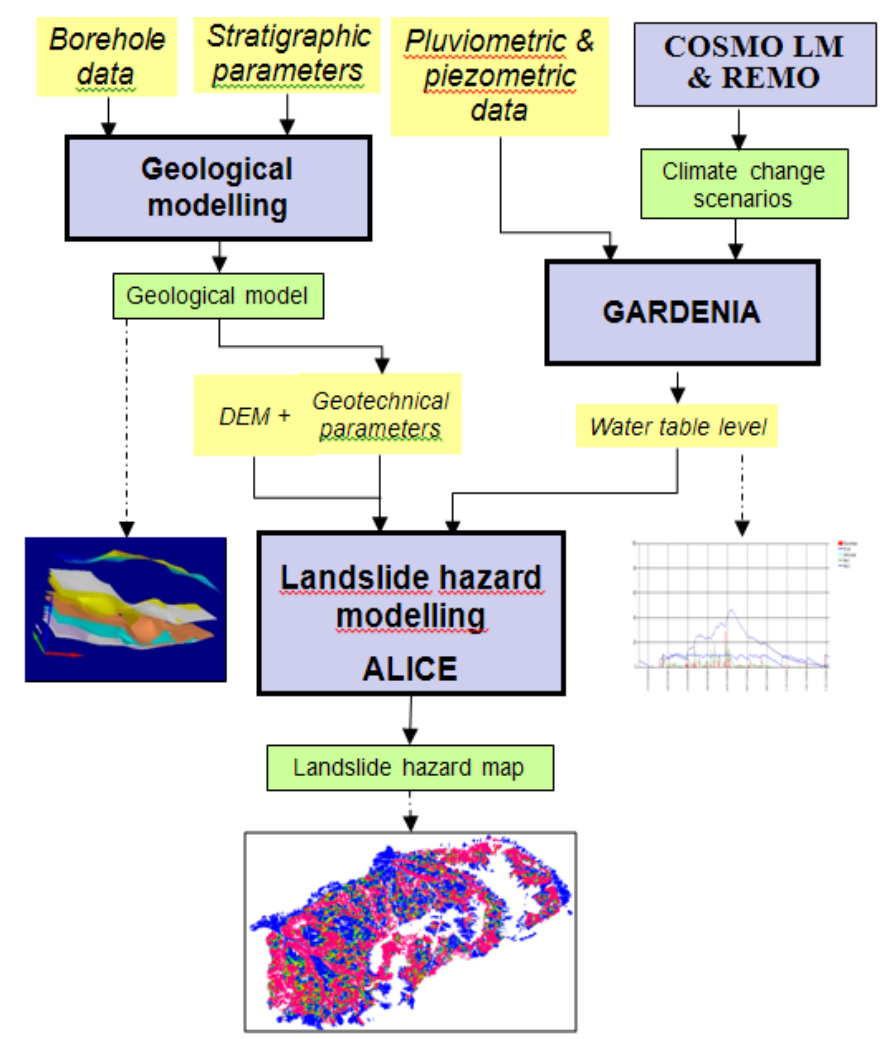

Figure 2: Chain of the methodology for coupling the hazard assessment tool with the hydrological model

\section{Application to an Alpine site: the Ubaye valley}

\section{Site presentation}

The studied site is a $350 \mathrm{~km}^{2}$ zone, situated in the south of France in the département Alpes de Haute Provence around the municipality of Barcelonnette. It is located in a mountainous area, reaching altitudes of approximately $3100 \mathrm{~m}$, with an average altitude of $1100 \mathrm{~m}$, and it is crossed by the Ubaye River.

The Barcelonnette Basin is characterized by a asymmetric valley. The north-facing slope is characterized by allochtonous sandstones outcrops and autochthonous marls. Dominated by black marls covered by moraine deposits ( 2 to $20 \mathrm{~m}$ ), its gentle slopes $\left(10-30^{\circ}\right)$ present an irregular topography with steep convex, planar and hummocky slopes. On the other side, the south-facing slope presents the steepest slopes $\left(35^{-}-75^{\circ}\right)$ which associated bar rocks on the upper part $\left(45^{-} 75^{\circ}\right)$, and screes on the lower part $\left(35^{-5} 0^{\circ}\right)$. The lower slopes associates convex and hummocky slopes $\left(15-30^{\circ}\right)$ and are covered by moraine deposits (Malet, 2003).

The landslide hazard is high in this area, the slopes being notably affected by severe gullying and both shallow and deep-seated large landslides (for example La Valette and Super-Sauze). Currently, many factors tend to make slopes unstable such as a dry and mountainous Mediterranean climate, with strong inter-annual rainfall variability. 


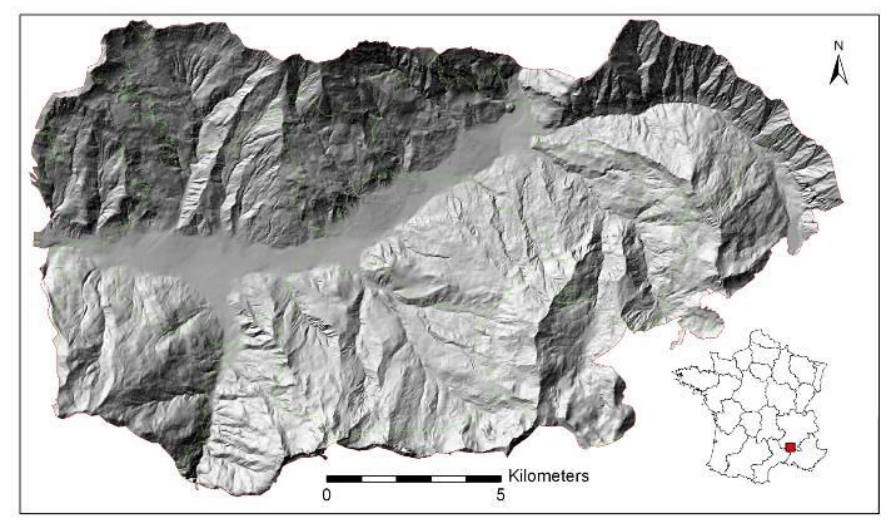

Figure 3: Study area location

\section{Data}

\section{Climate data}

The regional climate model REMO (Jacob, 2001) provides basic information on possible future changes in the European climate until the end of the 21 st century at a spatial scale of $25 \mathrm{~km}$. These simulations have been carried out under the SRES emission scenario A1B within the European ENSEMBLES project. They have been used as boundary conditions of dedicated REMO simulations at a very high resolution of $10 \mathrm{x} 10 \mathrm{~km}^{2}$ for the period 1950-2050 in the area of the Alps.

The second phase of the study consists in applying the non-hydrostatic COSMO Lokal Modell with a resolution of $3.8 \mathrm{x}$ $3.8 \mathrm{~km}^{2}$ to the results of the REMO simulations. In this way, a physically consistent simulation of small scale climatic features, e.g., local precipitation extremes and other landslide triggering events, is possible and can be linked to geomechanical models used for high resolution case studies.

\section{Geotechnical data}

A simplified geological model has been established from an engineering soil map (Thiéry, 2007). For the first ALICE ${ }^{\circledR}$ runs, it has been decided to divide the area in 10 different geotechnical zones. Each zone is represented by a soil column made of 3 layers called soil units (the lower one is bedrock). Each soil unit is characterized by its thickness and several geotechnical parameters such as friction angle, dry density and cohesion. Because laboratory tests do not always supply large-scale parameters some of them have been determined thanks to expert judgement. In a first step, constant values have been used.
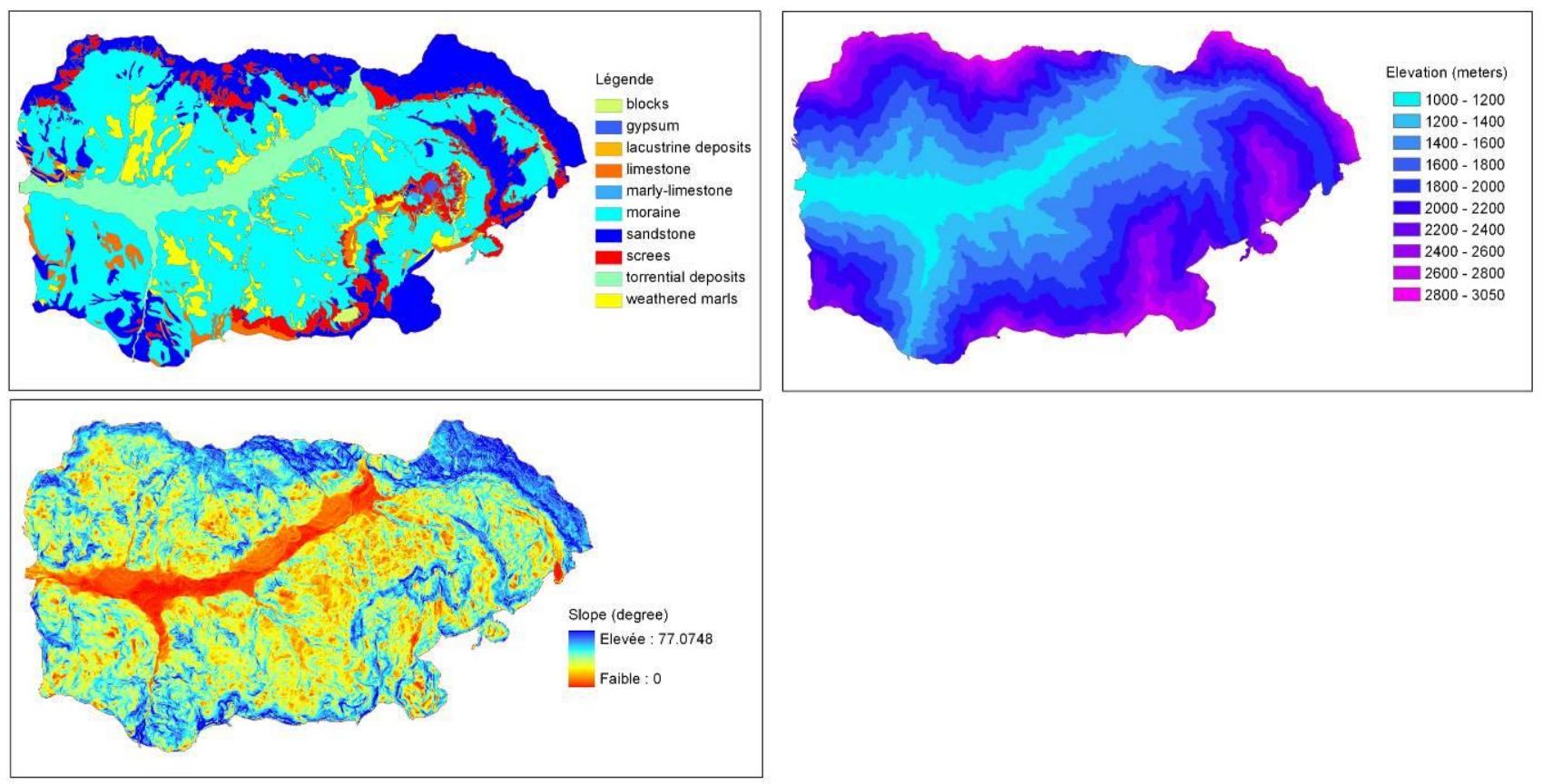

Figure 4: Main data used in the model: geotechnical zones, elevation model (resolution: $10 \mathrm{~m}$ ) and slope map (resolution: $10 \mathrm{~m}$ ) 
Before being able to use climate change data (COSMO Lokal Modell simulations were still running when the study began), the methodology was tested using 3 different water table scenarios. These scenarios cover the two extreme cases: the minimum water level (filling ratio=o), corresponding to a drought period and the maximal one (filling ratio=1), corresponding to period of heavy and lasting rainfall; and an average situation (filling ratio=0.5). The safety factor calculation also needs the landslide type (rotational or translational) and its length. These parameters were defined for the whole studied area and, for now, only 5om-rotational slides were considered.

\section{Results}

The whole chain was run with the 3 different filling ratios, providing 3 maps of safety factors (Figure 5). These preliminary results show that, as expected, an increase of the water content of the soil (e.g. in our case due to a long period of rainfall) induces a reduction in the safety factor, and a decrease in the water level makes the slopes more stable. These changes are not uniform over the area. Effects of water-table changes are more pronounced on profiles with steepest slopes.
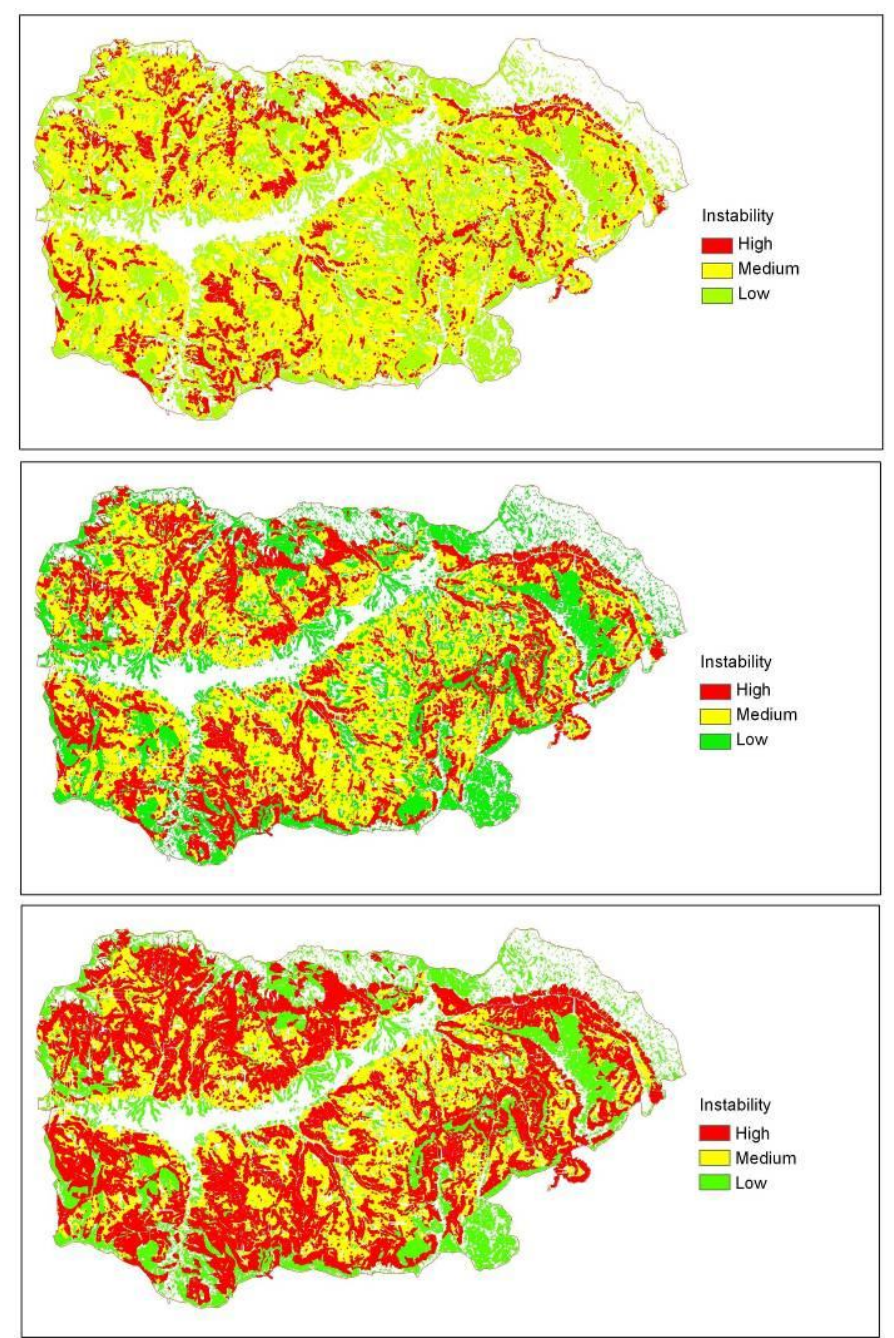

Figure 5: Representation of instability resulting from the simulations using the 3 different filling ratios. The ratio is o (top), o.5 (middle) and 1 (bottom).

\section{Conclusion and perspectives}

Dealing with risks requires an evaluation of what the future could be. Thus, changes in triggering factors have to be taken into account in hazard assessment, and not only qualitatively, but also quantitatively. In order to cope with this issue, a method was proposed here.

A hydrological model (GARDENIA ${ }^{\circledast}$ ) is combined with a quantitative landslide assessment model (ALICE ${ }^{\circledast}$ ) to allow the integration of climatic scenarios into landslide susceptibility mapping. 
The results presented here are only preliminary results and were shown to demonstrate the feasibility of the method. In the near future, the following developments will be presented.

- Uncertainties and variability of the geotechnical parameters would be quantified thanks to probabilistic distributions.

- Monte Carlo simulations will be performed to provide probabilistic information on safety factors.

- The hydrogeological model will be completed, taking into account the unsaturated part of soils.

- Analysis will be done for the different types and lengths of landslides, which occur in the area.

- Geotechnical models will be refined.

- Climate change data will be used to evaluate changing patterns of landslide activity.

\section{Acknowledgments}

The geotechnical data were provided by Jean-Philippe Malet from CNRS, France, and climatic data were provided Pasquale Schiano from CMCC- Centro Euro-Mediterraneo per I Cambiamenti Climatici s.c.a.r.l, Italy, in collaboration with MPG - Max Planck Gesellschaft zur Förderung der Wissenschaften e.V., Germany. The SafeLand project is cofunded by BRGM and the European Commission under the 7th Framework Programme for Research and Technological Development, Area "Environment", Activity 1.3.3.1 "Prediction of triggering and risk assessment for landslides".

\section{References}

Jacob D, (2001) A note to the simulation of the Annual and Interannual Variability of the Water Budget over the Baltic Sea Drainage Basin. Meteorology and Atmospheric Physics, 58, No. 1-4, 61-74.

Malet J P, (2003) Les 'glissements de type écoulement' dans les marnes noires des Alpes du Sud. Morphologie, fonctionnement et modélisation hydro-mécanique. PhD thesis, Université Louis Pasteur, Strasbourg, France.

Morgenstern N R, Price VE, (1967) A numerical method for solving the equations of stability of general slip surfaces. Computer Journal. $9: 388$ 393

Olivier M, Sedan O, Monod B, (2011) Contribution of physical modeling to landslide hazard mapping: case of the French Basque coast. Proceedings of the $2^{\text {nd }}$ World Landslide Forum, 3- October 2011. Rome, Italy. (this issue)

Sedan O, (2011) Logiciel ALICE version 7 - Guide Utilisateur. BRGM report. RP-60004-FR. 31p.

Thiéry D, (2003) Logiciel GARDÉNIA version 6.0 - Guide d'utilisation. BRGM report. RP-52832-FR. 104p.

Thiéry $\mathrm{Y}$, (2007) Susceptibilité du Bassin de Barcelonnette (Alpes du sud, France) aux 'mouvements de versant' : cartographie morphodynamique, analyse spatiale et modélisation probabiliste. PhD Thesis, Université de Caen, Caen, France. 